\title{
PENGARUH INFLASI TERHADAP RETURN SAHAM PADA PERUSAHAAN PROPERTI DAN REAL ESTATE YANG TERDAFTAR DI BURSA EFEK INDONESIA (RISIKO SISTEMATIS DAN PROFITABILITAS SEBAGAI VARIABEL MEDIASI)
}

\author{
Made Ayu Desy Geriadi ${ }^{1}$ \\ I Gusti Bagus Wiksuana ${ }^{2}$ \\ ${ }^{1,2}$ Fakultas Ekonomi dan Bisnis Universitas Udayana (Unud), Bali, Indonesia \\ email: desy.geriadi12@gmail.com
}

\begin{abstract}
ABSTRAK
Penelitian ini bertujuan untuk mengetahui pengaruh inflasi terhadap return saham, risiko sistematis dan profitabilitas sebagai variabel mediasi pada perusahaan properti dan real estate yang terdaftar di Bursa Efek Indonesia. Populasi dalam penelitian ini adalah perusahaan properti dan real estate yang terdaftar di Bursa Efek Indonesia. Pengambilan sampel penelitian dilakukan dengan metode purposive dan jumlah sampel penelitian ini sebanyak 25 perusahaan. Data penelitian merupakan data sekunder yang diperoleh dari website Bursa Efek Indonesia dan Indonesia Capital Market Directory dari tahun 2011 sampai dengan tahun 2015. Pengujian hipotesis penelitian menggunakan teknik analisis jalur (path analysis), dengan alat bantu aplikasi SPSS.Hasil penelitian menunjukkan bahwa: (1) inflasi berpengaruh negatif dan signifikan terhadap return saham. (2) risiko sistematis berpengaruh positif dan signifikan terhadap return saham. (3) profitabilitas berpengaruh positif dan signifikan terhadap return saham. (4) inflasi berpengaruh positif dan signifikan terhadap risiko sistematis (5) inflasi berpengaruh positif dan signifikan terhadap profitabilitas. Risiko sistematis dan profitabilitas tidak memediasi pengaruh inflasi terhadap return saham.
\end{abstract}

Kata Kunci : Inflasi, Risiko Sistematis,, Profitabilitas, dan Return Saham

\begin{abstract}
This study aims to determine the effect of inflation on stock returns, systematic risk and profitability as a mediation variable on property companies and real estate companies listed on the Indonesia Stock Exchange. The population in this study are property and real estate companies listed on the Indonesia Stock Exchange. The sampling of the research was done by purposive method and the number of samples were 25 companies. The research data is secondary data obtained from Indonesia Stock Exchange website and Indonesia Capital Market Directory from 2011 until 2015. Testing of research hypothesis using path analysis technique, with tool of SPSS application. The result of research shows that: (1) inflation has a negative and significant effect on stock return. (2) systematic risk has a positive and significant effect on stock return. (3) profitability have positive and significant effect to stock return. (4) inflation has a positive and significant effect on systematic risk (5) inflation has a positive and significant effect on profitability. Systematic risk and profitability do not mediate the effect of inflation on stock returns.
\end{abstract}

Keywords: Inflation, Systematic Risk, Profitability, and Stock Return 


\section{PENDAHULUAN}

Sektor properti dan real estate merupakan salah satu diantara beberapa sektor saham yang ada di Bursa Efek Indonesia. Perusahaan yang bergerak dalam sektor properti dan real estate saat ini berkembang dengan pesat. Kemajuan dan perkembangan bisnis ini menjadi daya tarik bagi para investor untuk berinvestasi pada perusahaan sektor properti dan real estate (Prasetyo dkk, 2013). Berdasarkan data Bareksa, indeks sektor properti dan sektor terkait bisnis properti tercatat sebagai sektor yang termasuk menghasilkan keuntungan (return) cukup besar, yakni melebihi 20 persen dari awal tahun hingga saat ini (www.bareksa.com).

Faktor-faktor yang mempengaruhi return saham adalah faktor makroekonomi dan faktor fundamental. Faktor makroekonomi berasal dari permasalahan ekonomi secara luas salah satunya inflasi. Faktor fundamental ini bisa dilihat dari laporan keuangan, dan dari laporan keuangan emiten bisa dilihat tingkat kinerja keuangannya baik dari segi kemampuan menghasilkan keuntungan (profitabilitas) (Sudarsono dan Sudiyatno, 2016).

Tingginya inflasi akan mendorong harga bahan bangunan menjadi semakin mahal, menyebabkan tingginya biaya produksi yang harus di tanggung oleh perusahaan. Penurunan daya beli dan biaya produksi yang tinggi secara tidak langsung akan mempengaruhi kondisi pasar modal. Investor tidak akan tertarik untuk menanamkan modalnya dan permintaan terhadap saham khususnya saham properti dan real estate menjadi turun (Purnomo dan Widyawati, 2013).

Rasio keuangan dapat membantu investor untuk mengidentifikasi kekuatan dan kelemahan suatu perusahaan, dengan melakukan analisis rasio 
keuangan investor akan memperoleh informasi tentang kondisi perusahaan dimasa sekarang, dimasa lampau dan bahkan dimasa yang akan datang (Syarifudin dan Fitria, 2013). Rasio keuangan yang digunakan pada penelitian ini adalah rasio profitabilitas yang diproksikan dengan Return on Asset (ROA). ROA mengukur kemampuan mengasilkan laba dari total aktiva yang digunakan (Wiagustini, 2010:81). Semakin besar ROA maka menunjukkan kinerja perusahaan yang semakin baik karena tingkat pengembalian (return) semakin besar (Prastowo, 2005:91).

Dampak inflasi akan dirasakan oleh seluruh perusahaan yang ada dalam industri. Kondisi ini akan berpengaruh pada kinerja pasar modal, karena banyak perusahaan tidak dapat beroperasi secara maksimal, akibatnya pasar modal menghadapi ketidakpastian yang tinggi. Investor yang rasional akan berusaha mendapatkan expected return maksimum dengan tingkat risiko minimum. Return biasanya berbanding lurus dengan risiko, yaitu semakin tinggi tingkat risiko yang dihadapi maka semakin tinggi return dari investasi tersebut, demikian sebaliknya. (Nugroho dan Triyonowati, 2013).

Inflasi yang tinggi akan mengakibatkan daya beli masyarakat menurun dan kenaikan tingkat bunga. Besar kecilnya laju inflasi akan mempengaruhi suku bunga dan kinerja keuangan perusahaan khususnya dari sisi profitabilitas. Inflasi yang terlalu tinggi akan menurunkan profitabilitas yang diperoleh oleh perusahaan begitu juga sebaliknya. Semakin besar nilai dari profitabilitas berarti bahwa semakin baik perusahaan menggunakan asetnya untuk mendapat laba. Hal ini membuat investor menjadi tertarik untuk membeli saham perusahaan serta 
berdampak pada harga saham yang semakin meningkat dan diikuti dengan tingkat pengembalian return saham yang tinggi (Arista, 2012 dalam Gunadi dan Kusuma, 2015).

Penelitian yang membahas mengenai inflasi dan return saham sudah banyak dilakukan dan mendapatkan hasil yang berbeda-beda. Penelitian yang dilakukan oleh Kuwornu (2012), Kudryavtsev (2014), Adusei (2014) menyatakan bahwa inflasi berpengaruh negatif terhadap return saham. Hasil penelitian tersebut berbeda dengan hasil penelitian yang dilakukan oleh Oshaibat (2016) menyatakan bahwa inflasi berpengaruh positif dan signifikan terhadap return saham. Sementara penelitian yang dilakukan oleh Purnomo dan Widyawati (2013), Mahilo dan Parengkuan (2013) dan Komariah dkk (2011) mendapatkan hasil bahwa inflasi tidak berpengaruh signifikan terhadap return saham.

Penelitian mengenai pengaruh risiko sistematis terhadap return saham dilakukan oleh Chen (2013), Aryani dkk (2015) menyatakan bahwa risiko sistematis memiliki pengaruh yang positif dan signifikan terhadap return saham. Berbeda dengan penelitian yang dilakukan oleh Musyarofah dkk (2015), Nugroho dan Sukhemi (2015) mendapatkan hasil bahwa risiko sistematis berpengaruh negatif dan signifikan terhadap return saham. Sementara penelitian yang dilakukan oleh Nugroho dan Triyonowati (2013) dan Artaya dkk (2014) menyatakan bahwa risiko sistematis tidak memiliki pengaruh terhadap return saham. 
Penelitian mengenai pengaruh profitabilitas terhadap return saham dilakukan oleh Bukit dan Anggono (2013), Syarifudin dan Fitria (2013), Susilowati dan Turyanto (2011) mendapatkan hasil bahwa ROA berpengaruh negatif dan signifikan terhadap return saham. Berbeda dengan penelitian yang dilakukan oleh Gunadi dan Kesuma (2015), Widyastuti (2007) mendapatkan hasil bahwa ROA berpengaruh positif dan signifikan terhadap return saham.

Ketidakkonsistenan hasil penelitian sebelumnya merupakan alasan menjadikan risiko sistematis dan profitabilitas sebagai variabel mediasi pada penelitian ini. Risiko sistematis dan profitabilitas diduga sebagai variabel lain yang turut mempengaruhi hubungan variabel infasi dengan return saham menjadi hubungan tidak langsung.

Dampak inflasi akan dirasakan oleh seluruh perusahaan yang ada dalam industri. Kondisi ini akan berpengaruh pada kinerja pasar modal, karena banyak perusahaan tidak dapat beroperasi secara maksimal, akibatnya pasar modal menghadapi ketidakpastian yang tinggi. Investor yang rasional akan berusaha mendapatkan expected return maksimum dengan tingkat risiko minimum. Risiko merupakan faktor utama yang menentukan besar kecilnya nilai pengembalian. Return biasanya berbanding lurus dengan risiko, yaitu semakin tinggi tingkat risiko yang dihadapi maka semakin tinggi return dari investasi tersebut, demikian sebaliknya. Oleh karena itu, sebelum investasi dilakukan, perlu pemahaman yang cukup atas investasi, sehingga risiko yang mungkin timbul di masa yang akan 
datang dapat diantisipasi, dan tingkat return dapat dioptimalkan (Nugroho dan Triyonowati, 2013).

Inflasi yang tinggi akan mengakibatkan daya beli masyarakat menurun dan kenaikan tingkat bunga. Besar kecilnya laju inflasi akan mempengaruhi suku bunga dan kinerja keuangan perusahaan khususnya dari sisi profitabilitas. Inflasi yang terlalu tinggi akan menurunkan profitabilitas yang diperoleh oleh perusahaan begitu juga sebaliknya. Semakin besar nilai dari ROA itu berarti bahwa semakin baik perusahaan menggunakan asetnya untuk mendapat laba, dengan meningkatnya nilai ROA profitabilitas dari perusahaan semakin meningkat. Hal ini membuat investor menjadi tertarik untuk membeli saham perusahaan serta berdampak pada harga saham yang semakin meningkat dan diikuti dengan tingkat pengembalian return saham yang tinggi (Arista, 2012 dalam Gunadi dan Kusuma, 2015).

\section{LANDASAN TEORI DAN HIPOTESIS}

\section{Signalling Theory}

Teori sinyal mengemukakan tentang pentingnya informasi yang dikeluarkan oleh perusahaan terhadap keputusan investasi. Informasi merupakan unsur penting bagi investor dan pelaku bisnis karena informasi menyajikan keterangan catatan dan gambaran masa lalu, saat ini maupun masa yang akan datang bagi perusahaan dan pasar modal. Informasi yang lengkap dan relevan serta akurat dan tepat waktu diperlukan investor pasar modal sebagai alat untuk menganalisis sebelum mengambil keputusan untuk berinvetasi. (Jogiyanto, 2013:392).

\section{Teori Penilaian Saham}


Terdapat dua pendekatan yang digunakan investor untuk menganalisis dan menilai harga satuan saham, yaitu analisis teknikal dan analisis fundamental. (Gitman, 2010:273).

\section{Analisis Teknikal}

Analisis ini beranggapan bahwa harga suatu saham akan ditentukan oleh permintaan dan penawaran terhadap harga tersebut, sehingga asumsi yang mendasari analisis teknikal, antara lain (Tandelilin, 2010:248):

1) Nilai pasar barang dan jasa ditentukan oleh interaksi permintaan dan penawaran.

2) Interaksi permintaan dan penawaran ditentukan oleh berbagai faktor, baik faktor rasional maupun faktor yang tidak rasional. Faktor-faktor tersebut meliputi berbagai variabel makroekonomi dan variabel fundamental serta faktor seperti opini yang beredar, mood investor dan ramalan-ramalan investor.

3) Harga-harga sekuritas secara individu dan nilai pasar secara keseluruhan cenderung bergerak mengikuti suatu tren selama jangka waktu yang relatif panjang.

4) Tren perubahan harga dan nilai pasar dapat berubah karena perubahan permintaan dan penawaran. Hubungan-hubungan tersebut akan dideteksi dengan melihat diagram reaksi pasar yang terjadi.

Analisis teknikal secara umum memfokuskan perhatian pada chart dari harga pasar sekuritas. Dow theory menyatakan bahwa pergerakan harga saham 
dibedakan menjadi tiga komponen, yaitu fluktuasi harian, pergerakan secara bulanan dan primary trend.

\section{Analisis Fundamental}

Menurut Tandelilin (2010:338), analisis fundamental dapat dilakukan secara top down approach melalui tiga tahapan, yaitu:

1) Analisis Ekonomi

Analisis ekonomi bertujuan untuk mengetahui jenis prospek bisnis suatu perusahaan. Analisis ekonomi merupakan analisis terhadap faktor-faktor eksternal dan bersifat makro berupa peristiwa-peristiwa yang terjadi di luar perusahaan dan mempengaruhi semua perusahaan, sehingga tidak dapat dikendalikan oleh perusahaan.

2) Analisis Industri

Analisi industri diperlukan untuk mengetahui kelemahan dan kekuatan jenis industri perusahaan yang bersangkutan. Hal-hal penting yang perlu dipertimbangkan pemodal dan analis saham misalnya seperti penjualan dan laba perusahaan, sikap dan kebijakan pemerintah terhadap industri, kondisi persaingan dan harga saham perusahaan sejenis.

3) Analisis Perusahaan

Analisis perusahaan digunakan untuk mengetahui kinerja perusahaan. Para penanam modal memerlukan informasi tentang perusahaan yang relevan sebagai dasar pembuatan kepuusan investasi. Informasi tersebut baik informasi internal dan eksternal perusahaan.

\section{Return Saham}


Menurut Mishkin dan Eakins (2009:259). "Investor can earn a return from stock in one of two ways. Either the price of the stock rises over time or the firm pays the stockholder devidends". Ketika orang membeli aset finansial, keuntungan atau kerugian dari investasi ini disebut return atas investasi. Total return atas investasi umumnya mempunyai dua komponen. Pertama, tunai apapun yang diterima ketika mempunyai investasi. Untuk saham, pembayaran tunai dari perusahaan kepada pemegang saham adalah deviden. Kedua, nilai aset yang dibeli mungkin berubah, yang berarti ada capital gain atau capital loss. Untuk saham, harganya bisa mengalami peningkatan sehingga pemegangnya dikatakan memperoleh capital gain atau juga bisa mengalami penurunan yang disebut capital loss (Tandelilin. 2010:26).

Menurut Jogiyanto (2013: 205) return dibagi menjadi dua macam, yaitu:

1. Return realisasi (realized return)

Return realisasi (realized return) merupakan return yang telah terjadi. Return realisasi dihitung dengan menggunakan data historis. Return realisasi penting karena digunakan sebagai salah satu pengukur kinerja dari perusahaan. Return realisasi atau return historis ini juga berguna sebagai dasar penentuan return ekspektasi (expected return) dan risiko dimasa datang.

2. Return ekspektasi (expected return)

Return ekspektasi (expected return) adalah return yang diharapkan akan diperoleh investor dimasa mendatang. Berbeda dengan return realisasi yang sifatnya sudah terjadi, return ekspektasi sifatnya belum terjadi. 


\section{Hipotesis Penelitian}

\section{Hubungan inflasi dengan return saham}

Tingkat inflasi yang tinggi biasanya dikaitkan dengan kondisi ekonomi yang terlalu panas (overheated). Artinya, kondisi ekonomi mengalami permintaan atas produk yang melebihi kapasitas penawaran produknya, sehingga hargaharga cenderung mengalami kenaikan. Disamping itu, inflasi yang tinggi juga bisa mengurangi tingkat pendapatan riil yang diperoleh investor dari investasinya (Tandelilin, 2010:342). Pengaruh inflasi terhadap return saham dalam penelitian yang dilakukan oleh Kuwornu (2012), Adusei (2014), Kudryavtsev (2014) mendapatkan hasil bahwa inflasi berpengaruh negatif terhadap return saham. Berdasarkan uraian tersebut maka dapat diketahui bahwa terdapat pengaruh yang negatif antara inflasi dengan return saham, sehingga dapat diajukan hipotesis sebagai berikut:

$\mathrm{H}_{1}=$ Inflasi berpengaruh negatif signifikan terhadap return saham.

\section{Hubungan risiko sistematis dengan return saham}

Konsep risk-return tradeoff merupakan hubungan antara risiko dan return yang biasanya dipegang, dalam mana seseorang akan menerima risiko yang lebih besar bila ingin memperoleh return yang lebih besar. Risiko merupakan faktor utama yang menentukan besar kecilnya nilai pengembalian (Nugroho dan Triyonowati, 2013). Pengaruh risiko sistematis terhadap return saham dalam penelitian yang dilakukan oleh Chen (2013), Chang (2011), Aryani dkk (2015) menyatakan risiko sistematis memiliki pengaruh yang positif dan signifikan terhadap return saham. Berdasarkan uraian tersebut maka dapat diketahui bahwa 
terdapat pengaruh yang positif antara risiko sistematis dengan return saham, sehingga dapat diajukan hipotesis sebagai berikut:

$\mathrm{H}_{2}=$ Risiko sistematis berpengaruh positif signifikan terhadap return saham.

\section{Hubungan profitabilitas dengan return saham}

Teori signalling menjelaskan bahwa jenis informasi yang dikeluarkan oleh perusahaan dapat menjadi sinyal bagi pihak luar perusahaan, terutama investor. Informasi yang lengkap, relevan, akurat dan tepat waktu sangat diperlukan oleh investor di pasar modal sebagai alat analisis untuk mengambil keputusan investasi. Semakin besar profitabilitas maka menunjukkan kinerja perusahaan yang semakin baik karena tingkat pengembalian (return) semakin besar. (Prastowo, 2005:91). Penelitian yang dilakukan oleh Gunadi dan Kesuma (2015), Widyastuti (2007) menyatakan ROA berpengaruh positif dan signifikan terhadap return saham. Berdasarkan uraian tersebut maka dapat diketahui bahwa terdapat pengaruh yang positif antara profitabilitas dengan return saham, sehingga dapat diajukan hipotesis sebagai berikut:

$\mathrm{H}_{3}=$ Profitabilitas berpengaruh positif signifikan terhadap return saham.

\section{Hubungan inflasi dengan risiko sistematis}

Inflasi adalah suatu keadaan pada saat daya beli masyarakat mengalami penurunan, tetapi saat inflasi stabil atau rendah maka tingkat daya beli masyarakat mengalami peningkatan (Fahmi, 2012:175). Pengaruh inflasi terhadap risiko sistematis dalam penelitian yang dilakukan oleh Suparno (2013) mendapatkan hasil bahwa inflasi berpengaruh positif signifikan terhadap risiko sistematis. Berdasarkan uraian tersebut maka dapat diketahui bahwa terdapat pengaruh yang 
positif antara inflasi dengan risiko sistematis, sehingga dapat diajukan hipotesis sebagai berikut:

$\mathrm{H}_{4}=$ Inflasi berpengaruh positif signifikan terhadap risiko sistematis

\section{Hubungan inflasi dengan profitabilitas}

Boediono (2011), menyatakan bahwa inflasi adalah kecenderungan dari harga-harga untuk naik secara umum dan terus-menerus. Inflasi yang tinggi akan mengakibatkan daya beli masyarakat menurun dan kenaikan tingkat bunga. Besar kecilnya laju inflasi akan mempengaruhi suku bunga dan kinerja keuangan perusahaan khususnya dari sisi profitabilitas. Inflasi yang terlalu tinggi akan menurunkan profitabilitas yang diperoleh oleh perusahaan begitu juga sebaliknya Pengaruh inflasi terhadap profitabilitas dalam penelitian yang dilakukan oleh Kalengkongan (2013), Malik et al. (2015), Vejzagic dan Zarafat (2014), Lee (2014) menyatakan nflasi memiliki pengaruh yang negatif dan signifikan terhadap ROA. Berdasarkan uraian tersebut maka dapat diketahui bahwa terdapat pengaruh yang negatif antara inflasi dengan profitabilitas, sehingga dapat diajukan hipotesis sebagai berikut:

$\mathrm{H}_{5}=$ Inflasi berpengaruh negatif signifikan terhadap profitabilitas.

\section{Risiko sistematis memediasi pengaruh inflasi terhadap return saham}

Inflasi yang terlalu tinggi menyebabkan penurunan daya beli uang (purchasing power of money). Disamping itu, inflasi yang tinggi juga bisa mengurangi tingkat pendapatan riil yang diperoleh investor dari investasinya (Tandelilin, 2010:342). Menurunnya kinerja perusahaan karena dampak inflasi akan dirasakan oleh seluruh perusahaan yang ada dalam industri. Kondisi ini akan 
berpengaruh pada kinerja pasar modal, karena banyak perusahaan tidak dapat beroperasi secara maksimal, akibatnya pasar modal menghadapi ketidakpastian yang tinggi. Risiko yang tinggi akan membuat investor berharap atas tingkat return yang tinggi pula, ketika risiko rendah maka tingkat return akan berpotensi rendah. (Musyarofah dkk, 2015). Berdasarkan uraian tersebut maka dapat diketahui bahwa risiko sistematis memediasi pengaruh inflasi terhadap return saham, sehingga dapat diajukan hipotesis sebagai berikut:

$\mathrm{H}_{6}=$ Risiko sistematis mampu memediasi pengaruh inflasi terhadap return saham.

\section{Profitabilitas memediasi pengaruh inflasi terhadap return saham}

Kondisi inflasi yang tinggi akan berpengaruh terhadap kenaikan biaya produksi. Biaya produksi yang tinggi akan menyebabkan harga jual barang-barang produksi naik, dan hal ini akan menurunkan daya beli masyarakat karena pendapatan riil masyarakat juga menurun. Menurunnya daya beli masyarakat mengakibatkan menurunnya penjualan perusahaan, dan menurunnya penjualan perusahaan akan menurunkan keuntungan perusahaan. Jika keuntungan perusahaan menurun, maka dapat dikatakan bahwa kinerja perusahaan juga menurun. Berdasarkan uraian tersebut maka dapat diketahui bahwa profitabilitas memediasi pengaruh inflasi terhadap return saham, sehingga dapat diajukan hipotesis sebagai berikut:

$\mathrm{H} 7$ = Profitabilitas mampu memediasi pengaruh inflasi terhadap return saham 
Berdasarkan uraian di atas, maka dapat digambarkan kerangka konseptual penelitian seperti pada Gambar 1.

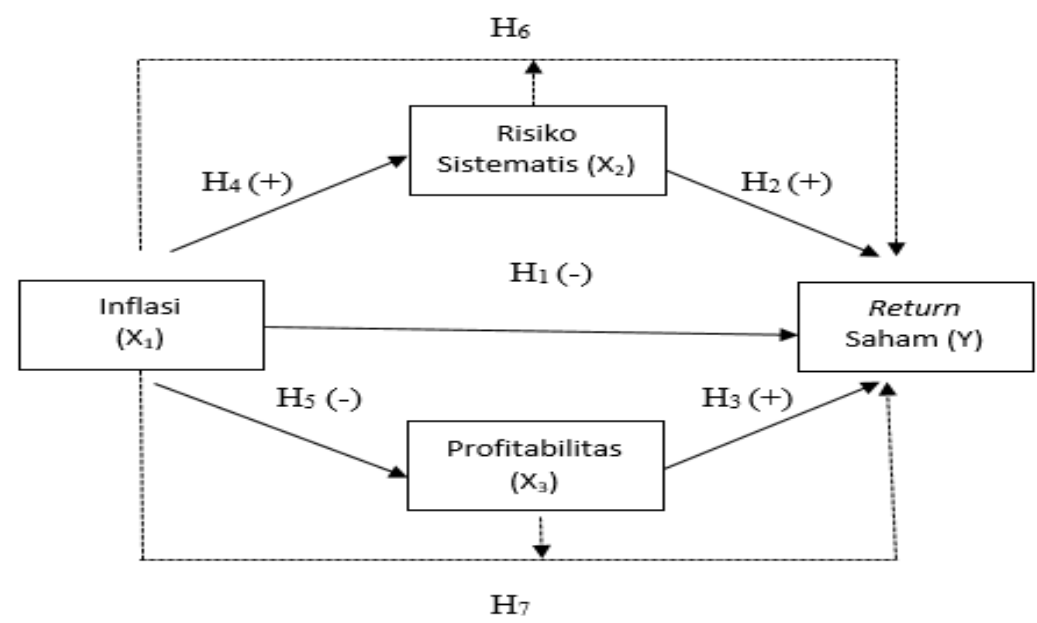

Sumber: Penelitian Terdahulu

Gambar 1. Kerangka Konseptual Penelitian

\section{METODE PENELITIAN}

Penelitian ini merupakan penelitian kausalitas dimana terdapat hubungan antara dua variabel atau lebih. Populasi dari penelitian adalah seluruh perusahaan yang tercatat dalam sektor properti dan real estate di Bursa Efek Indonesia periode 2011-2015 yaitu sebanyak 54 perusahaan. Teknik sampling yang digunakan adalah teknik purposive sampling, sehingga didapatkan 25 perusahaan yang menjadi sampel dalam penelitian ini. Metode pengumpulan data yang digunakan yaitu data sekunder. Teknik analisis data menggunakan analisis jalur (path analysis).

\section{HASIL DAN PEMBAHASAN}

\section{Analisis Deskriptif}


Statistik deskriptif digunakan untuk memberikan gambaran umum tentang objek penelitian yang dijadikan sampel. Statistik deskriptif masing-masing variabel dapat dilihat pada Tabel 1 berikut:

\section{Tabel 1}

Hasil Uji Deskriptif

\begin{tabular}{|c|c|c|c|c|c|}
\hline & $\mathbf{N}$ & Minimum & Maximum & Mean & Std. Deviation \\
\hline Inflasi $\left(\mathrm{X}_{1}\right)$ & 125 & 0,0436 & 0,0697 & 0,05920 & 0,009211 \\
\hline Risiko Sistematis $\left(\mathrm{X}_{2}\right)$ & 125 & $-2,796$ & 6,350 & 1,39543 & 1,285845 \\
\hline \multicolumn{6}{|l|}{ Profitabilitas $\left(\mathbf{X}_{\mathbf{3}}\right)$} \\
\hline Return Saham (Y) & 125 & 0,002 & 0,273 & 0,07533 & 0,047737 \\
\hline & 125 & $-0,518$ & 1,133 & 0,17490 & 0,361590 \\
\hline
\end{tabular}

Sumber : Output SPSS

Berdasarkan Tabel 1 dapat dilihat bahwa variabel inflasi (X1) terendah (minimum) selama periode pengamatan yaitu 0,0436 dan inflasi tertinggi (maksimum) selama periode pengamatan yaitu 0,0697. Variabel risiko sistematis $\left(\mathrm{X}_{2}\right)$ yang diproksikan beta memiliki nilai beta terendah (minimum) selama periode pengamatan yaitu -2,796 sedangkan beta tertinggi (maksimum) selama periode pengamatan yaitu 6,350. Variabel profitabilitas (X3) yang diproksikan dengan Return On Assets (ROA) memiliki nilai terendah (minimum) selama periode pengamatan yaitu 0,002 sedangkan ROA tertinggi (maksimum) selama periode pengamatan yaitu 0,273. Nilai variabel Return Saham terkecil adalah sebesar -0,518 dan return saham terbesar adalah sebesar 1,133.

\section{Pengujian Validitas Model}

Evaluasi terhadap validitas model dapat dilihat dari koefisien determinasi total persamaan struktur dari model penelitian berikut ini:

$\mathrm{R}_{1}=0,481$

$\mathrm{R}_{2}=0,178$ 
$\mathrm{R}_{3}=0,196$

$P e_{i}=\sqrt{\left(1-R^{2}\right)}$

Maka :

$$
\begin{aligned}
& \mathrm{Pe}_{1}=0,877 \\
& \mathrm{Pe}_{2}=0,984 \\
& \mathrm{Pe}_{3}=0,981
\end{aligned}
$$

Koefisien determinasi total $\left(\mathrm{R}^{2} \mathrm{~m}\right)$

$$
\mathrm{R}^{2} \mathrm{~m}=1-\mathrm{P}^{2} \mathrm{e}_{1} \times \mathrm{P}^{2} \mathrm{e}_{2} \times \mathrm{P}^{3} \mathrm{e}_{3}
$$

Maka:

$$
\begin{aligned}
& R^{2} m=1-0,877^{2} \times 0,984^{2} \times 0,981^{2} \\
& R^{2} m=1-0.769 \times 0,968 \times 0,962 \\
& R^{2} m=1-0,716 \\
& R^{2} m=0,284
\end{aligned}
$$

Koefisien determinasi total sebesar 0,284 mempunyai arti bahwa $28,4 \%$ return saham dapat dijelaskan oleh inflasi, risiko sistematis dan profitabilitas. Sisanya yaitu sebesar $71,6 \%$ dijelaskan oleh variabel lain yang tidak diteliti dalam penelitian ini.

\section{Hasil Pengujian Hipotesis}

Dalam pengujian hipotesis satu sampai lima ini yang menjadi perhatian adalah pengaruh langsung dan signifikan yang ditunjukkan oleh anak panah antar variabel pada penelitian ini. 


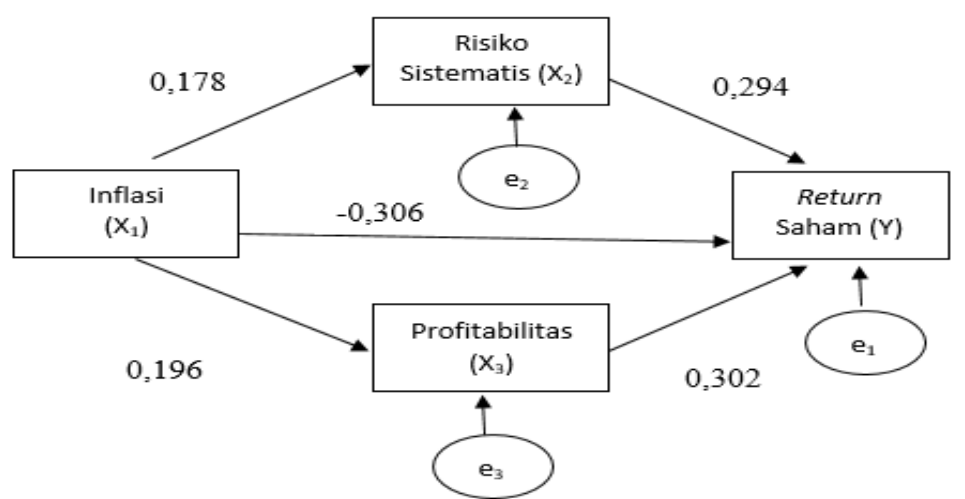

Gambar 2. Kerangka Konseptual Penelitian

Sumber : output spss

Berdasarkan Gambar 2, hasil analisis menunjukkan bahwa nilai koefisien jalur yang diperoleh dari hubungan antara variabel inflasi dengan return saham sebesar $-0,306$ pada tingkat signifikansi $\alpha=5 \%$ dan $p$ value $=0,000$. Dengan demikian, hipotesis yang menyatakan bahwa inflasi berpengaruh negatif signifikan terhadap return saham terbukti.

Hasil analisis menunjukkan bahwa nilai koefisien jalur yang diperoleh dari hubungan antara variabel risiko sistematis dengan return saham sebesar 0,294 pada tingkat signifikansi $\alpha=5 \%$ dan $\mathrm{p}$ value $=0,000$. Dengan demikian, hipotesis yang menyatakan bahwa risiko sistematis berpengaruh positif signifikan terhadap return saham terbukti.

Hasil analisis menunjukkan bahwa nilai koefisien jalur yang diperoleh dari hubungan antara variabel profitabilitas dengan return saham sebesar 0,302 pada tingkat signifikansi $\alpha=5 \%$ dan $\mathrm{p}$ value $=0,000$. Dengan demikian, hipotesis yang menyatakan bahwa profitabilitas berpengaruh positif signifikan terhadap return saham terbukti. 
Hasil analisis menunjukkan bahwa nilai koefisien jalur yang diperoleh dari hubungan antara variabel inflasi dengan risiko sistematis sebesar 0,178 pada tingkat signifikansi $\alpha=5 \%$ dan $\mathrm{p}$ value $=0,047$. Dengan demikian, hipotesis yang menyatakan bahwa inflasi berpengaruh positif signifikan terhadap risiko sistematis terbukti.

Hasil analisis menunjukkan bahwa nilai koefisien jalur yang diperoleh dari hubungan antara variabel inflasi dengan profitabilitas sebesar 0,196 pada tingkat signifikansi $\alpha=5 \%$ dan $\mathrm{p}$ value $=0,029$. Dengan demikian, hipotesis yang menyatakan bahwa inflasi berpengaruh negatif signifikan terhadap profitabilitas ditolak.

Uji sobel dilakukan untuk menguji hipotesis 6 dan hipotesis 7 pengaruh mediasi dalam sebuah model. Hasil pengujian sobel dapat dilihat sebagai berikut:

a) Risiko Sistematis Memediasi Pengaruh Inflasi terhadap Return Saham

Tabel 2

Koefisien Regresi dan Standard Error

\begin{tabular}{llc}
\hline Hubungan & Koefisien & Standard Error \\
\hline $\mathbf{X}_{\mathbf{1}} \rightarrow \mathbf{X}_{\mathbf{2}}(\boldsymbol{\alpha})$ & 0,178 & 12,387 \\
$\mathbf{X}_{\mathbf{2}} \rightarrow \mathbf{Y}$ (b) & 0,294 & 0,083 \\
\hline
\end{tabular}

Sumber : Output spss

$S a b=\sqrt{b^{2} S a^{2}+a^{2} S b^{2}+S a^{2} S b^{2}}$

$S a b=\sqrt{0,294^{2} 12,387^{2}+0,178^{2} 0,023^{2}+12,387^{2} 0,023^{2}}$

$S a b=\sqrt{13,2625+0,0000+-0,0812}$

$S a b=\sqrt{13,3437}$

$S a b=3,652907$

Untuk menguji signifikansi pengaruh tidak langsung, maka kita perlu menghitung nilai t dari koefisien ab dengan rumus sebagai berikut:

$$
\begin{aligned}
t & =\frac{a b}{S a b} \\
t & =\frac{0,178 \times 0,294}{3,652907}
\end{aligned}
$$




$$
\begin{aligned}
t & =\frac{0,0523}{3,652907} \\
t & =0,0143
\end{aligned}
$$

Berdasarkan perhitungan diatas dapat dilihat bahwa t hitung $=0,0143$ lebih kecil dari 1,96 hal ini berarti bahwa risiko sistematis tidak mampu memediasi pengaruh inflasi terhadap return saham.

b) Profitabilitas Memediasi Pengaruh Inflasi terhadap Return Saham

Tabel 3

Koefisien Regresi dan Standard Error

\begin{tabular}{llc}
\hline Hubungan & Koefisien & Standard Error \\
\hline $\mathbf{X}_{\mathbf{1}} \rightarrow \mathbf{X}_{\mathbf{3}}(\boldsymbol{\alpha})$ & 0,196 & 0,458 \\
$\mathbf{X}_{\mathbf{3}} \rightarrow \mathbf{Y}(\mathbf{b})$ & 0,302 & 0,621 \\
\hline
\end{tabular}

Sumber: Output spss

$$
\begin{aligned}
& S a b=\sqrt{0,302^{2} 0,458^{2}+0,196^{2} 0,621^{2}+0,458^{2} 0,621^{2}} \\
& S a b=\sqrt{0,0191+0,0148+-0,0809} \\
& S a b=\sqrt{0,1148} \\
& S a b=0,33888 \\
& \text { Menghitung t hitung: }
\end{aligned}
$$

$$
\begin{aligned}
t & =\frac{0,302 \times 0,196}{0,33888} \\
t & =\frac{0,0592}{0,33888} \\
t & =0,1747
\end{aligned}
$$

Berdasarkan perhitungan diatas dapat dilihat bahwa $\mathrm{t}$ hitung $=0,1747$

lebih kecil dari 1,96 hal ini berarti bahwa profitabilitas tidak mampu memediasi pengaruh inflasi terhadap return saham.

\section{Pembahasan}

\section{Pengaruh Inflasi terhadap Return Saham}

Berdasarkan hasil penelitian ini dapat diartikan bahwa variabel inflasi terhadap return saham memiliki pengaruh yang negatif dan signifikan. Hasil penelitian ini menunjukkan bahwa perubahan inflasi akan menyebabkan 
penurunan sebesar 30,6\% pada return saham perusahaan properti dan real estate dan sebaliknya. Dengan demikian jika angka inflasi naik, maka harga saham perusahaan properti dan real estate akan menurun. Hal ini akan diikuti oleh penurunan return saham (Tatik, 2013). Hasil penelitian ini mendukung penelitian yang dilakukan oleh Kuwornu (2012), Adusei (2014) dan Kudryavtsev (2014) yang mendapatkan hasil inflasi berpengaruh negatif terhadap return saham, artinya semakin kuat inflasi maka return saham perusahaan perusahaan properti dan real estate akan mengalami penurunan.

\section{Pengaruh Risiko Sistematis terhadap Return Saham}

Berdasarkan hasil penelitian ini dapat diartikan bahwa variabel risiko sistematis terhadap return saham memiliki pengaruh yang positif dan signifikan. Hasil penelitian ini menunjukkan bahwa perubahan risiko sistematis akan menyebabkan peningkatan sebesar $29,4 \%$ pada return saham perusahaan properti dan real estate dan sebaliknya. Hasil ini sesuai dengan konsep risk-return tradeoff. Risiko merupakan faktor utama yang menentukan besar kecilnya nilai pengembalian. Return biasanya berbanding lurus dengan risiko, yaitu semakin tinggi tingkat risiko yang dihadapi maka semakin tinggi return yang diharapkan dari investasi tersebut, demikian sebaliknya. Hasil penelitian ini mendukung penelitian yang dilakukan oleh Chen (2013), Chang (2011), Aryani dkk (2015) yang menyatakan risiko sistematis memiliki pengaruh yang positif dan signifikan terhadap return saham. Semakin tinggi risiko maka return saham perusahaan properti dan real estate akan mengalami peningkatan.

\section{Pengaruh Profitabilitas terhadap Return Saham}


Berdasarkan hasil penelitian ini dapat diartikan bahwa variabel profitabilitas terhadap return saham memiliki pengaruh yang positif dan signifikan. Hasil penelitian ini menunjukkan bahwa perubahan profitabilitas akan menyebabkan peningkatan sebesar $30,2 \%$ pada return saham perusahaan properti dan real estate dan sebaliknya. Hal ini menguatkan teori signalling yang menyatakan bahwa salah satu jenis informasi yang dikeluarkan oleh perusahaan dapat menjadi sinyal bagi pihak luar perusahaan, terutama investor. Hasil penelitian ini mendukung penelitian yang dilakukan oleh Gunadi dan Kesuma (2015), Widyastuti (2007) yang menyatakan ROA berpengaruh positif dan signifikan terhadap return saham. ROA semakin meningkat maka return saham perusahaan properti dan real estate akan mengalami peningkatan.

\section{Pengaruh Inflasi terhadap Risiko Sistematis}

Berdasarkan hasil penelitian ini dapat diartikan bahwa variabel inflasi terhadap risiko sistematis memiliki pengaruh yang positif dan signifikan. Hasil penelitian ini menunjukkan bahwa perubahan inflasi akan menyebabkan peningkatan sebesar $17,8 \%$ pada risiko sistematis perusahaan properti dan real estate dan sebaliknya. Menurunnya kinerja perusahaan karena dampak inflasi akan dirasakan oleh seluruh perusahaan yang ada dalam industri. Kondisi ini akan berpengaruh pada kinerja pasar modal, karena banyak perusahaan tidak dapat beroperasi secara maksimal, akibatnya pasar modal menghadapi ketidakpastian yang tinggi (Sudiyatno dan Nuswandhari, 2009). Hasil penelitian ini mendukung penelitian yang dilakukan oleh Santosa (2009), Setiawan (2009) dan Suparno (2013) yang menemukan bahwa inflasi memiliki pengaruh secara positif dan 
signifikan terhadap risiko sistematis. Inflasi dan risiko sistematis memiliki hubungan yang searah. Inflasi yang meningkat akan mengakibatkan meningkatnya risiko sistematis.

\section{Pengaruh Inflasi terhadap Profitabilitas}

Berdasarkan hasil penelitian ini dapat diartikan bahwa variabel inflasi terhadap profitabilitas memiliki pengaruh yang positif dan signifikan. Hasil penelitian ini menunjukkan bahwa perubahan inflasi akan menyebabkan peningkatan sebesar $30,2 \%$ pada probabilitas perusahaan properti dan real estate dan sebaliknya. Perusahaan yang memiliki fundamental yang kuat tidak akan terpengaruh oleh adanya inflasi. Hasil penelitian ini mendukung penelitian yang dilakukan oleh Sahara (2013), Tan dan Floros (2012), yang menyatakan inflasi memiliki pengaruh yang positif dan signifikan terhadap profitabilitas. Semakin tinggi inflasi maka profitabilitas perusahaan properti dan real estate akan mengalami peningkatan

\section{Risiko Sistematis tidak mampu memediasi pengaruh Inflasi terhadap Return}

\section{Saham}

Hasil uji sobel menunjukkan bahwa risiko sistematis tidak memediasi hubungan inflasi dan return saham. Berdasarkan perhitungan didapatkan nilai $\mathrm{t}$ hitung=0,0143 lebih kecil dari 1,96 hal ini berarti bahwa tidak terdapat pengaruh mediasi risiko sistematis dalam hubungannya dengan inflasi dan return saham. Pengaruh inflasi terhadap return saham merupakan pengaruh langsung. Pengaruh ini tidak dimediasi oleh risiko sistematis, oleh karena itu tidak terjadi pengaruh berjenjang antara inflasi, risiko sistematis dan return saham 


\section{Profitabilitas Tidak Mampu Memediasi Pengaruh Inflasi Terhadap Return}

\section{Saham}

Hasil uji sobel menunjukkan bahwa profitabilitas tidak memediasi hubungan inflasi dan return saham. Berdasarkan perhitungan didapatkan nilai $\mathrm{t}$ hitung=0,1747 lebih kecil dari 1,96 hal ini berarti bahwa tidak terdapat pengaruh mediasi profitabilitas dalam hubungannya dengan inflasi dan return saham. Hal ini dikarenakan perubahan profitabilitas tidak berdampak signifikan terhadap pengaruh inflasi terhadap return saham perusahaan properti dan real estate.

\section{SIMPULAN DAN SARAN}

Berdasarkan hasil penelitian dapat disimpulkan bahwa inflasi berpengaruh negatif dan signifikan terhadap return saham, risiko sistematis return saham memiliki pengaruh yang positif dan signifikan, profitabilitas memiliki pengaruh yang positif dan signifikan terhadap return saham, inflasi memiliki pengaruh yang positif dan signifikan terhadap risiko sistematis, inflasi memiliki pengaruh yang positif dan signifikan terhadap profitabilitas, risiko sistematis dan profitabilitas tidak mampu memediasi hubungan inflasi dan return saham.

Berdasarkan temuan-temuan dan kesimpulan penelitian, disarankan beberapa hal yang penting sebagai berikut yaitu bagi perusahaan properti dan real estate yang terdaftar di BEI harus memperhatikan pengaruh inflasi, risiko sistematis dan profitabilitas karena akan berpengaruh terhadap return saham perusahaan. Perusahaan properti dan real estate harus meningkatkan laba dan meningkatkan efisiensi perusahaan dalam penggunaan aset. Hal tersebut akan mempengaruhi 
persepsi dan keputusan investor terkait dengan membeli saham perusahaan tersebut.

Bagi investor yang ingin berinvestasi dalam bentuk saham pada perusahaan properti dan real estate di BEI, investor sebaiknya lebih memperhatikan tingkat inflasi, risiko sistematis dan profitabilitas perusahaan. Investor dapat mengidentifikasi perusahaan yang memiliki nilai profitabilitas yang tinggi dengan memperhatikan peningkatan laba dan efisiensi perusahaan dalam penggunaan asetnya.

Penelitian ini masih terdapat keterbatasan dalam pengukuran variabel makro ekonomi dan kinerja perusahaan sehingga peneliti selanjutnya dapat memasukkan beberapa pengukuran, seperti pendapatan domestik bruto (PDB), tingkat suku bunga, nilai tukar rupiah dan Return on Equity (ROE) sehingga variabelnya konstruk (tidak terukur) dan dapat menggunakan analisis SEM. Peneliti selanjutnya juga dapat menggunakan data yang lebih pendek, seperti data triwulan.

\section{Implikasi Penelitian}

1) Implikasi Teoritis

Hasil penelitian ini menyatakan bahwa inflasi, risiko sistematis dan profitabilitas memiliki pengaruh signifikan terhadap return saham perusahaan sektor properti dan real estate di Bursa Efek Indonesia.

a) Hasil penelitian ini mendukung teori kuantitas yang menyatakan bahwa harga barang berbanding lurus dengan jumlah uang yang beredar. Inflasi akan cenderung meningkatkan biaya produksi dari 
perusahaan sehingga margin keuntungan dari perusahaan menjadi lebih rendah dan dampak lebih lanjut menjadikan harga sahamnya di bursa efek menjadi menurun.

b) Hasil penelitian ini juga mendukung konsep risk-return tradeoff dimana seseorang akan menerima risiko yang lebih besar bila ingin memperoleh return yang lebih besar.

c) Hasil penelitian ini mendukung teori signalling yang menyatakan bahwa salah satu jenis informasi yang dikeluarkan oleh perusahaan dapat menjadi sinyal bagi pihak luar perusahaan, terutama investor.

2) Implikasi Praktis

Hasil penelitian ini memberikan implikasi praktis bahwa faktor inflasi, risiko sistematis dan profitabilitas berperan penting dalam membuat keputusan investasi. Inflasi yang semakin meningkat memberikan sinyal negatif terhadap return saham perusahaan properti dan real estate. Semakin tinggi risiko sistematis maka semakin tinggi return saham perusahaan properti dan real estate. Nilai ROA yang tinggi juga berperan dalam memberikan informasi dan sinyal positif untuk return saham perusahaan properti dan real estate.

\section{REFERENSI}

Adusei, M. 2014. The Inflation Stock Market Returns Nexus : Evidence from the Ghana Stock Exchange. Journal of Economics and International Finance, $38-46$.

Aryani , A., Tandika, D., \& Azib. 2015. Pengaruh Risiko Sistematis terhadap Return Saham (Studi Kasus Sektor Property yang terdaftardi Bursa Efek Indonesia Periode Tahun 2010-2014). Prosiding Manajemen, 16. 
Boediono. 2011. Ekonomi Moneter. Edisi 3. BPFE. Yogyakarta.

Chang, M. C. 2011 Reexamination of Capital Asset Pricing Model (CAPM): An Application of Quantile Regression. African Journal of Business Management Vol. 5(33), pp. 12684-12690.

Chen, M. 2013. Analisis Pengaruh Perekonomian Makro dan Mikro yang Berpengaruh pada Risiko Sistematis Saham. Jurnal Nominal Volume III No 2, 1-26.

Chen, M.2015. Risk Return Trade Off in Chinese Stock Markets : some recent evidence. International Journal of Emerging Markets Vol. 10 No. 3, 448473.

Fahmi, I. 2012. Pengantar Pasar Modal. Bandung: Alfabeta.

Gitman, L. J. 2012. Principles of Manajerial Finance International. $13^{\text {th }}$ Edition. Boston: Pearson Edition.

Gunadi, G. G., \& Kesuma, I. W. 2015. Pengaruh ROA, DER, EPS Terhadap Return Saham Perusahaan Food and Beverage BEI. E-Jurnal Manajemen Unud Vol 4 No 6, 1636-1647.

Jogiyanto, H. 2013. Teori Portofolio dan Analisis Investasi. Yogyakarta: BPFE.

Kalengkongan, G. 2013. Tingkat Suku Bunga dan Inflasi Pengaruhnya Terhadap Return on Asset (ROA) pada Industri Perbankkan yang Go Public di Bursa Efek Indonesia. Jurnal EMBA Vol 1 No 4, 737-747.

Kudryavtsev, A., Levav, E., \& Shahrabani, S. 2014. Effect of Inflation on Nominal and Real Stock Returns : A Behavioral View. Journal of Advanced Studies in France, 56-65.

Kuwornu, J. K. 2012. Effect of Macroeconomic Variables on the Ghanaian Stock Market Returns: A Co-Integration Analysis. Agris online Papers in Economics and Informatics Volume IV Number 2, 1-13.

Lee, C.Y.2014. The Effects Of Firm Specific Factors And Macroeconomics On Profitability Of Property-Liability Insurance Industry In Taiwan. Asian Economic and Financial Review. 681-691

Malik, R., Baig, S. A., Abbass, Z., \& Rehman, M. Z. 2015. Bank Peculiar, Macroeconomic Causes and Profitability of Banks: An Evidence from Pakistan. International Journal of Information, Business and Management Vol 7 No 4, 1-15.

Musyarofah, S.,x Suhadak, \& Hidayat, R. R. 2015. Pengaruh Beta Pasar dan Deviden Payout Ratio Terhadap Return Saham (Studi Pada Perusahaan Perbangkan yang Terdaftar di Bursa Efek Indonesia Periode 2010-2013`). Jurnal Administrasi Bisnis Vol 26 No 2, 1-8. 
Nugroho, I. J. \& Triyonowati 2013. Pengaruh Risiko Sistematis dan Faktor Fundamental Terhadap Return Saham Perusahaan Otomotif. Jurnal Ilmu \& Riset Manajemen Vol 2No12, 1-22.

Prastowo, D. 2005. Analisis Laporan Keuangan Konsep dan Aplikasi. Yogyakarta: Upp.Amp YPKN.

Purnomo, T. H., \& Widyawati, N. 2013. Pengaruh Nilai Tukar, Suku Bunga dan Inflasi terhadap Return Saham pada Perusahaan Properti. Jurnal Ilmu \& Riset Manajemen Vol 2 No 10, 1-20.

Santosa, Antonius Heru. 2009. Analisis Risiko Investasi Saham pada Sektor Properti di Bursa Efek Indonesia. Jurnal Universitas Gunadarma, Jakarta.

Setiawan, Aris Budi. 2009. Analisis Risiko Investasi Saham pada Sektor Properti di Bursa Efek Indonesia. Jurnal Universitas Gunadarma, Jakarta.

Sudarsono, B., \& Sudiyatno B 2016. Faktor-Faktor Yang Mempengaruhi Return Saham Pada Perusahaan Property dan Real Estate Yang Terdaftar Pada Bursa Efek Indonesia Tahun 2009 S/D 2014. Jurnal Bisnis dan Ekonomi. $30-51$

Sudiyatno, B., \& Nuswandhari, C. 2009. Peran Beberapa Indikator Ekonomi dalam Mempengarhi Risiko Sistematis Perusahaan Manufaktur di Bursa Efek Indonesia Jakarta. Dinamika Kuangan dan Perbangkan Vol 1 No 2, 66-81.

Suparno. 2013. Tingkat Inflasi dan Rasio Likuiditas terhadap Risiko Saham Syariah. Jurnal Telaah \& Rasio Likuiditas Terhadap Risiko Saham Syariah, 1-9.

Syarifudin, N., \& Fitria, A. 2013. Analisis Pengaruh Rasio Profitabilitas dan Rasio Pasar Terhadap Return Saham. Jurnal Ilmu \& Riset Akuntansi Vol 2 No 2, 1-17.

Tan, Y., \& Floros, C. 2012. Bank Profitability and Inflation the Case of China. Journal of Economic Studies Vol 39 No 6, 675-696.

Tandelilin, E. 2010. Analisis Investasi dan Manajemen Portofolio. Yogyakarta: BPFE.

Tatik, 2013. Inflasi, Kurs, Leverage, Profitabiitas dan Return Saham Perusahaan Farmasi Go Publik Bei 2008-2012. Jurnal Ilmu Manajemen Vol 1 No 3, 735-745.

Vejzagic, M., \& Zarafat, H. 2014. An Analysis of Macroeconomic Determinants of Commercial Banks Profitability in Malaysia for The Period 19952011. Asian Economic and Financial Review, 41-57.

Wiagustini, N. 2010. Dasar-Dasar Manajemen Keuangan. Denpasar: Udayana Univesity Press. 
Made Ayu Desy Geriadi dan I Gusti Bagus Wiksuana, Pengaruh Inflasi Terhadap Return Saham...

Widyastuti, T. 2007. Pengaruh Karakteristik Perusahaan terhadap Manajemen Laba dan Dampaknya pada Return Saham. Jurnal Akuntabilitas, 38-4 